\title{
ENHANCING THE DURABILITY OF CONCRETE MADE OF CONCRETE RECYCLATE BY ADDITIVES AND ADMIXTURES
}

\author{
Michal STEHLÍK \\ Department of Building Testing, Faculty of Civil Engineering, TU of Brno, \\ Veveři 95, 60200 Brno, Czech Republic \\ Received 12 Dec 2011; accepted 27 Aug 2012
}

\begin{abstract}
The aim of this research is to find an optimum combination of silicate admixtures and epoxy dispersion additives which would positively influence the durability and mechanical properties of concretes made of concrete recyclate. The durability of concrete is dependent on its cover layer permeability and also on the overall permeability of concrete recyclate. The cover layer permeability was evaluated by means of three methods, namely the air permeability method TPT and two methods of measuring water permeability, GWT and ISAT. Fine silicate admixtures and dispersion additives influence the air and water permeability of concrete made of concrete recyclate in different ways. The dose of $10 \%$ of microsilica or $30 \%$ of slag or fly ash decreases the air permeability of concrete. Water permeability, on the other hand, is decreased by adding a dose of $12 \%$ of pure epoxy dispersion. As regards improving the mechanical properties of concrete made of concrete recyclate, it seems to be promising to use a combination of $30 \%$ of slag admixture or $10 \%$ of microsilica admixture with $12 \%$ of epoxy dispersion additive. However, the price of admixtures and additives is relatively high. That is why additive enhanced concretes made of concrete recyclate are intended for special purposes.
\end{abstract}

Keywords: concrete recyclate, durability, permeability, epoxy dispersion, penetration, slag, fly ash, microsilica.

Reference to this paper should be made as follows: Stehlík, M. 2014. Enhancing the durability of concrete made of concrete recyclate by additives and admixtures, Journal of Civil Engineering and Management 20(2): $270-279$. http://dx.doi.org/10.3846/13923730.2013.802708

\section{Introduction}

The production of structural elements and structures in the building industry is affected not only by the sales, but primarily by the cost of raw materials and of their processing. The possibility of replacing natural aggregate with concrete recyclate is directly connected with the economic and environmental issues (Pytlík 2009; Henry et al. 2011). The use of recyclates could lower the number of building waste dumps in future, but it is necessary to carry out further research in this sphere. If we compare the properties of natural dense aggregate and concrete recyclate, the recyclate comes out worse. Especially due to a great variety in the quality of broken concrete (Mlčochová 2006; Rao et al. 2007), a lower strength of cement paste and an increased proportion of fine particles in the concrete recyclate (Škopán 2006). The strength of cement paste, i.e. of the concrete recyclate matrix, is usually lower, compared with the filler from natural dense aggregate, and therefore limiting for the strength characteristics of concrete recyclate.

The quality of construction work is assessed nowadays on the basis of three criteria: load-bearing capacity, serviceability and useful life (Vavřín, Retzl 1987; Śmerda et al. 1999). Concretes in which natural aggregate is replaced with the more absorbent concrete recyclate are characterized by a shorter service life (GómezSoberón 2002; Sun, Jiang 2010). Aggressive substances affecting concrete from outer environment can shorten service life and cause degradation of all concrete types (Matoušek, Drochytka 1998; Pavlík et al. 2007). The mechanism of degradation depends primarily on the current state of pores in the structure of the cover layer of concrete (covercrete). The formation and character of covercrete are determined by the manufacturing technology of concrete specimens. During compaction air bubbles move upwards. Thus concrete gets rid of air, but some bubbles remain near the surface. Simultaneously, fine particles are concentrated near the walls of the form (fine fractions of aggregate and hydrated cement), which leads to increasing the surface porosity. Due to the geometry of coarse aggregate, the surface of aggregate does not get close to the form or to its corners. This process is called wall effect. That is why the properties of the several-centimetre layer (from 20 to $50 \mathrm{~mm}$ ) near the surface of concrete are usually worse than those of the remaining material. Permeation processes of covercrete are affected by transport processes and they correspond directly to the character of pores in the structure of concrete (Zaharieva et al. 2003). The evaluation of durability is therefore derived directly from its permeation properties (Claisse et al. 2009). The permeation properties include mainly 
the structure permeability for gas and water, sorptivity, initial absorption capacity, water tightness, diffusion, etc.

The aim of research presented here is to find an optimum combination of silicate admixtures and dispersion additives for designing formulations for concrete made of concrete recyclate with a markedly more favourable durability properties. The first experiments with the additives of chemicals into concrete made of concrete recyclate in CR were carried out e.g. by Klimešová et al. (2001), a positive influence of mineral admixtures on the performance of concrete from concrete recyclate was proved by Corinaldesi and Moriconi (2009). The additionally determined mechanical properties of the tested concretes will be compared with the results from the previous research (Stehlík et al. 2010a, b). It is apparent that durability, or potentially permeability, of concrete surface is not only influenced by the choice of materials and formulation of fresh mixture. Also important is the placement, compaction and mainly curing of concrete at the beginning and in the course of hardening. The permeability of surface layers of tested concretes was evaluated by means of three methods. The TPT (Torrent Permeability Test) method evaluates the air permeability of concrete by reducing the vacuum (Romer 2005), the GWT (German Water Test) method measures the pressure water permeability and the ISAT (Initial Surface Absorption Test) method measures the initial surface absorption.

The issue of testing or designing concrete mixtures for the purpose of improving the durability properties of concretes made of concrete recyclate has been addressed so far by a number of scholars (Corinaldesi, Moriconi 2009; Debieb et al. 2010; Sun, Jiang 2010; Kwan et al. 2012). Some of them added puzzolana (Izaguirre et al. 2010) or fly ash (Bai, Gailius 2009) into the mixture, others impregnated the raw recyclate with a PVA dispersion (Stehlík et al. 2010a, b; Cui, Xiang 2011). The permeability of the surface layer of concrete and consequently the durability was tested using the standard chloride permeability method, the capillary water absorption test or the oxygen Cembureau method (Claisse et al. 1997). Zaharieva et al. (2003) tried to determine the areal permeability of concrete layer for water and air. Almost all of the above mentioned authors came to the conclusion that it is not possible to improve the properties of concrete made of concrete recyclate by creating one model formulation with the precisely defined doses of additives and admixtures, because of the unclear origin and heterogeneity of properties of concrete recyclates from various waste dumps (Škopán 2006). The research presented in this paper tries to extend the knowledge achieved up to now (Sebök 1985; Richardson 1988; Ohama 1995; Hwang et al. 2007; Novák et al. 2008; Henry et al. 2011; Stehlík 2011a) with some newly designed combinations of silicate admixtures (namely fly ash, slag and microsilica) and epoxy dispersion additives (meant to be put into the batch of water and for the penetration of the surface of grains of the concrete recyclate) improving the durability properties of the economically and ecologically promising concretes made of concrete recyclate.

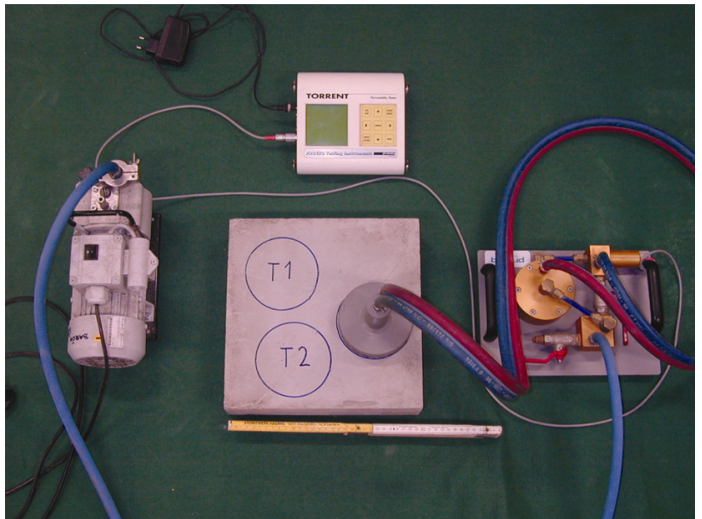

Fig. 1. Set for measuring air permeability on a concrete slab $300 \times 300 \times 80 \mathrm{~mm}$ using the TORRENT method, three horizontal positions of measurement

\section{Principles of Torrent, GWT and ISAT permeability tests}

The TORRENT device for testing permeability works in connection with a vacuum pump (Fig. 1). The basic components of the device are a two-chamber vacuum cell and a pressure regulator providing for the air-flow into the inner chamber oriented perpendicularly to the tested surface. The measurement method enables calculating the coefficient of permeability $k_{T}$ on the basis of the determined theoretical model. The coefficient of permeability $k_{T}$ for the tested cover layer of concrete (max. depth of vacuum creation is $50 \mathrm{~mm}$ ) is read from the display of the evaluating unit after an automatic completion of the measurement.

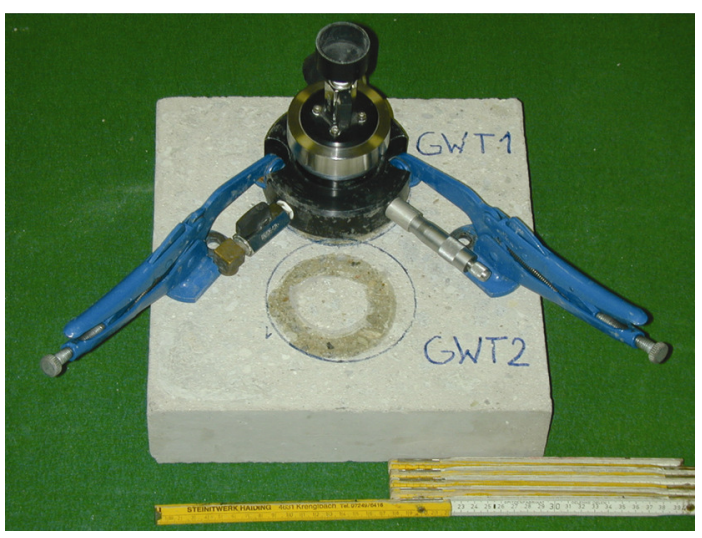

Fig. 2. Set for measuring pressure water permeability on a concrete slab using the GWT method, two horizontal positions of measurement

The GWT device (Fig. 2) is designated for measuring pressure water permeability of the cover layer on the basis of a direct contact with the surface of concrete specimen (max. range of measurability, i.e. the max. penetration of water is the depth of $30 \mathrm{~mm}$ ). The sealed pressure chamber is put on the concrete surface, filled with previously boiled water, and the given water pressure acts upon the concrete surface. The water pressure is kept at a chosen constant level by an attached piston of a micrometer gauge which compensates for the loss of water, and thus the volume of water penetrated into the concrete is 
measured. The reference quantity is the flow (flow rate) of water $(Q)$ passing through the layer of concrete that can be calculated from the following equation:

$$
Q=\frac{B \cdot\left(g 1-g_{2}\right)}{A \cdot t}\left[\mathrm{~mm} \cdot \mathrm{s}^{-1}\right],
$$

where: $B$ is the area of the micrometer gauge piston exerting pressure on the water in the chamber $\left(B=78.6 \mathrm{~mm}^{2}\right)$ for the piston diameter $\varnothing 10 \mathrm{~mm} ; A$ is the area of concrete surface on which water in the chamber exerts pressure $\left(A=3018 \mathrm{~mm}^{2}\right)$ for chamber diameter $\varnothing 62 \mathrm{~mm} ; g_{1}$ and $g_{2}$ are the readings on the micrometer gauge before and after the test in $\mathrm{mm}$; and $t$ is the time of test performance in seconds.

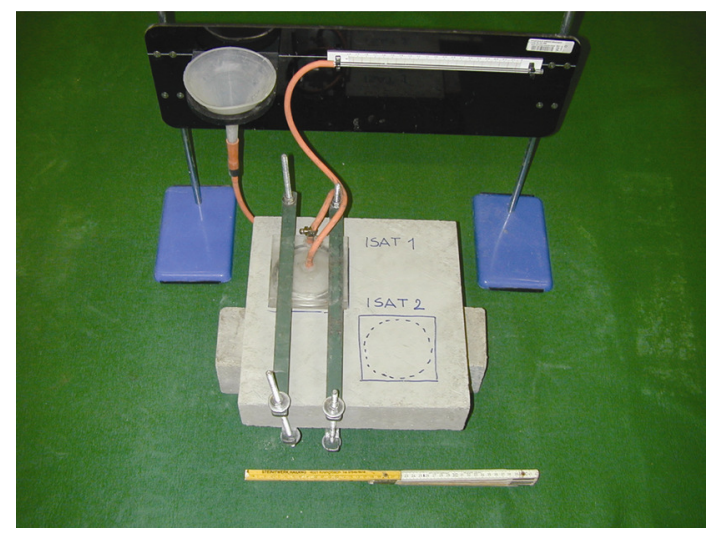

Fig. 3. Set for measuring initial absorption on a concrete slab using the ISAT method, two horizontal positions of measurement

The device for determining the initial surface absorption, ISAT (Fig. 3), is able to indicate the flow rate of water through the dry and smooth concrete surface. The maximum depth of measurability is $10 \mathrm{~mm}$ considering the mere $200 \mathrm{~mm}$ water column overpressure. The essence of the test is to determine the time necessary for the flow of a given volume of water into the concrete surface through a calibrated capillary. The reference quantity is the flow of a given volume of water $(F)$ through the surface of concrete:

$$
F=\frac{60}{t} \cdot D \cdot 0,01\left[\mathrm{~mm} \cdot \mathrm{m}^{-2} \cdot \mathrm{s}^{-1}\right],
$$

where: $t$ is the interval of measurement in seconds; $D$ is the number of flown-through scale divisions of the capillary during the interval $t$.

\section{Materials}

\subsection{Aggregates}

The reference concretes not containing aggregates from the concrete recyclate were made from natural dense aggregates of three fractions in accordance with ČSN EN 12620 Aggregates into Concrete - see Table 1. The proportion of all three fractions was chosen with a view to achieving the optimum voids content of approx. $25 \%$, the ratio of fraction $0-4 \mathrm{~mm}: 4-8 \mathrm{~mm}$ then $1: 3$ by volume.
When preparing the test concretes, the coarse fraction 8 $16 \mathrm{~mm}$ of the Olbramovice natural aggregate was replaced with raw concrete recylcate from the Dufonev s.r.o. with a fraction of 0-16 mm (Stehlík et al. 2010a, b), or with a 4-31.5 $\mathrm{mm}$ recyclate penetrated in advance with solvent-free epoxy dispersion CHS EPOXY 160V55. Recycling lines are usually not able to produce concrete recyclate containing only the most demanded narrow fraction of $8-16 \mathrm{~mm}$. The coarse recyclate also contains the technologically produced fine and medium fraction of 0-8 mm (see Fig. 4, blue curve). Unfortunately, fine fraction of the recyclate of $0-4 \mathrm{~mm}$, created by crushing the cement paste, is not suitable for concrete because of its high absorption capacity. That is why manufacturers reduce its volume to the $20 \%$ of the total volume of concrete recyclate - see Figure 4 . When designing a formulation of concrete with a substitution of coarse fraction of $8-16 \mathrm{~mm}$ with the concrete recyclate of $0-16 \mathrm{~mm}$, it is necessary to adjust (slightly decrease) the dose of natural dense fraction of $0-4 \mathrm{~mm}$ and $4-8 \mathrm{~mm}$ considering up to the $30 \%$ content of these fractions in the concrete recyclate of $0-16 \mathrm{~mm}$. However, this adjustment of formulation is not necessary in case of using concrete recyclate penetrated in advance (original fraction $0-16 \mathrm{~mm}$, after penetration $4-31.5 \mathrm{~mm}$ ). The fraction increase (i.e. increasing the diameter of concrete recyclate grains by adding fine fraction to the coarse fraction using epoxy dispersion - see grading curves in Fig. 4) to $4-31.5 \mathrm{~mm}$ in the penetrated recyclate in comparison with the $0-16 \mathrm{~mm}$ natural one is given by an agglomeration of fine and course grains due to dispersion. The aim of the experimental penetration of the natural raw recyclate was to decrease the excessively high absorption capacity, determined according to EN 1097-6, which corresponded to $10.5 \%$, measured by weighing after 10 minutes. However, the permissible standard value of absorption capacity of type 1 concrete recyclate is only $10 \%$, measured by weighing after 10 minutes. That is why in one of the variants of the tested formulations for concretes made of concrete recyclate the raw recyclate was experimentally penetrated with the same procedure described in Stehlík et al. (2010a) and Stehlík (2011a, b). Penetration of raw recyclate was made with a waterborne epoxy dispersion CHS Epoxy 160V55 + hardener Telalit 1261, mixing ratio100:11.5 recommended by Novák (2009) after the dilution of dispersion : water $=2: 1$ by volume. This penetration decreased the absorption capacity of the concrete recyclate to $5.5 \%$.

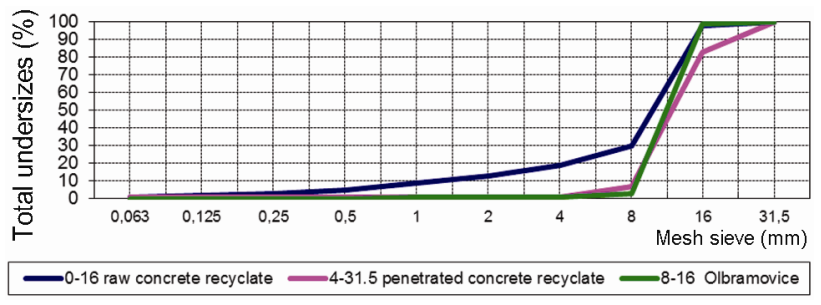

Fig. 4. Grading curves of raw and penetrated concrete recyclate and natural dense aggregate Olbramovice 
Table 1. Bulk weight and apparent porosity of aggregates natural dense, raw and penetrated concrete recyclate

\begin{tabular}{|c|c|c|c|c|c|}
\hline 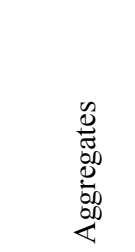 & 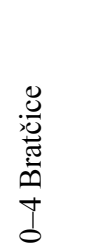 & $\begin{array}{l}\overrightarrow{0} \\
20 \\
0 \\
0 \\
0 \\
0 \\
0 \\
0\end{array}$ & 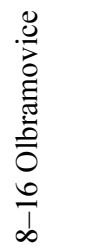 & 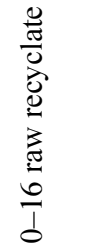 & 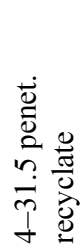 \\
\hline $\begin{array}{l}\text { Bulk } \\
\text { weight }\end{array}$ & $\begin{array}{c}1420 \\
\mathrm{~kg} / \mathrm{m}^{3}\end{array}$ & $\begin{array}{l}1445 \\
\mathrm{~kg} / \mathrm{m}^{3}\end{array}$ & $\begin{array}{c}1500 \\
\mathrm{~kg} / \mathrm{m}^{3}\end{array}$ & $\begin{array}{c}1135 \\
\mathrm{~kg} / \mathrm{m}^{3}\end{array}$ & $\begin{array}{c}965 \\
\mathrm{~kg} / \mathrm{m}^{3}\end{array}$ \\
\hline $\begin{array}{l}\text { Apparent } \\
\text { porosity }\end{array}$ & $0.8 \%$ & $1.2 \%$ & $0.7 \%$ & $10.5 \%$ & $6.0 \%$ \\
\hline
\end{tabular}

\subsection{Additives}

The raw concrete recyclate was penetrated with the socalled type III modern solvent-free epoxy dispersion CHS EPOXY 160V55 (hereinafter E 160V55), produced by SYNPO Pardubice a. s., CR (Novák et al. 2006; Novák 2009). The dispersion viscosity amounts to $400 \mathrm{mPa} . \mathrm{s} / 25^{\circ} \mathrm{C}$; the content of non-volatile components is $57 \%$, the content of volatile components, the so-called "VOC" (volatile organic components) is $0 \mathrm{~g} / l$. As a hardener component, we used Telalit 1040 dosed in the mass ratio of $100: 10$. The viscosity of the hardener is $25 \mathrm{mPa} . \mathrm{s} / 25^{\circ} \mathrm{C}$.

\subsection{Admixtures}

For improving the durability properties of concretes made of concrete recyclate, three types of fine silicate admixtures (Table 2) were alternately added (Schulze et al. 1990; Bilir 2011). Ground granulated blast-furnace slag is produced in the Dětmarovice power plant and is supplied by Cemex $\mathrm{CR}$, dosed at the amount of $30 \%$ of cement mass per $1 \mathrm{~m}^{3}$ of concrete; Fly ash for concrete is produced in the Chvaletice power plant and is supplied by Cemex CR, dosed at the amount of $30 \%$; Microsilica is produced by Romex Romania, dosed at the amount of $10 \%$.

Table 2. Specific surface, bulk weight and density of admixtures

\begin{tabular}{l|ccc}
\hline \multicolumn{1}{c|}{ Admixture } & Slag & Fly ash & Microsilica \\
\hline $\begin{array}{l}\text { Specific } \\
\text { surface }\end{array}$ & $420 \mathrm{~m}^{2} / \mathrm{kg}$ & $240 \mathrm{~m}^{2} / \mathrm{kg}$ & $2350 \mathrm{~m}^{2} / \mathrm{kg}$ \\
\hline Bulk weight & $1100 \mathrm{~kg} / \mathrm{m}^{3}$ & $840 \mathrm{~kg} / \mathrm{m}^{3}$ & $260 \mathrm{~kg} / \mathrm{m}^{3}$ \\
\hline Density & $2900 \mathrm{~kg} / \mathrm{m}^{3}$ & $2000 \mathrm{~kg} / \mathrm{m}^{3}$ & $2200 \mathrm{~kg} / \mathrm{m}^{3}$ \\
\hline
\end{tabular}

\subsection{Specimens and formulations}

In total we made 12 concrete slabs with the dimensions of $300 \times 300 \times 80 \mathrm{~mm}$ (the dimensions of slabs are more suitable for the testing of surface permeability compared to the standard cubes). Out of these, 6 slabs were made of concretes according to basic formulations R1-R6 (Tables 3-5) another 6 slabs then from the basic-formulation concretes treated with a $12 \%$ addition of epoxy dispersion into the batch of water - marked R1E-R6E (Table 6). The composition of the R1 reference concrete mixture (dense aggregate) was designed for strength class $\mathrm{C} 35 / 45$, for-

mulations R2-R6 (concrete recyclate) for strength class C 25/30, both at a consistency of S1 (slump 10-40 mm according to ČSN EN 4103). The composition of the reference formulation and tested formulations of concrete without addition of epoxy dispersion is specified in Tables 3-5. Concretes with the addition of dispersion have the same composition, but in addition to that they contain $12 \%$ of epoxy dispersion of the mass of cement, with the resulting consistency of S3 (100-150 mm slump according to C CNN ISO 4103).

The change in slump class from S1 to $\mathrm{S} 3$ is the consequence of the technology of common batches during the manufacture of six different pairs of concrete

Table 3. Formulations of concrete mixtures I

\begin{tabular}{|c|c|c|c|}
\hline \multicolumn{2}{|c|}{$\begin{array}{c}\text { Formulation R1 } \\
\text { Reference formulation, } \\
\text { natural coarse aggregate } \\
\text { Olbramovice, fraction } \\
8-16 \mathrm{~mm}\end{array}$} & \multicolumn{2}{|c|}{$\begin{array}{c}\text { Formulation } \mathbf{R 2} \\
100 \% \text { of natural coarse } \\
\text { aggregate } 8-16 \mathrm{~mm} \text { substi- } \\
\text { tuted with raw concrete } \\
\text { recyclate } 0-16 \mathrm{~mm}\end{array}$} \\
\hline CEM I 42,5 R & $300 \mathrm{~kg} / \mathrm{m}^{3}$ & CEM I 42,5 R & $300 \mathrm{~kg} / \mathrm{m}^{3}$ \\
\hline $\begin{array}{c}0-4 \\
\text { Bratčice }\end{array}$ & $800 \mathrm{~kg} / \mathrm{m}^{3}$ & 0-4 Bratčice & $760 \mathrm{~kg} / \mathrm{m}^{3}$ \\
\hline $\begin{array}{c}4-8 \\
\text { Tovačov }\end{array}$ & $250 \mathrm{~kg} / \mathrm{m}^{3}$ & 4-8 Tovačov & $228 \mathrm{~kg} / \mathrm{m}^{3}$ \\
\hline $\begin{array}{c}8-16 \\
\text { Olbramovice }\end{array}$ & $912 \mathrm{~kg} / \mathrm{m}^{3}$ & $\begin{array}{l}0-16 \text { raw } \\
\text { concrete } \\
\text { recyclate }\end{array}$ & $690 \mathrm{~kg} / \mathrm{m}^{3}$ \\
\hline water & $136 \mathrm{~kg} / \mathrm{m}^{3}$ & water & $159 \mathrm{~kg} / \mathrm{m}^{3}$ \\
\hline
\end{tabular}

Table 4. Formulations of concrete mixtures II

\begin{tabular}{|c|c|c|c|}
\hline \multirow{2}{*}{\multicolumn{2}{|c|}{$\begin{array}{c}\text { Formulation } \mathbf{R 3} \\
100 \% \text { of natural coarse aggre- } \\
\text { gate } 8-16 \mathrm{~mm} \text { substituted } \\
\text { with penetrated concrete } \\
\text { recyclate } 4-31.5 \mathrm{~mm}\end{array}$}} & \multirow{2}{*}{\multicolumn{2}{|c|}{$\begin{array}{l}\text { Formulation } \mathbf{R 4} \\
100 \% \text { of natural coarse } \\
\text { aggregate } 8-16 \mathrm{~mm} \text { substi- } \\
\text { tuted with raw concrete } \\
\text { recyclate } 0-16 \mathrm{~mm}\end{array}$}} \\
\hline & & & \\
\hline CEM I 42,5 R & $300 \mathrm{~kg} / \mathrm{m}^{3}$ & CEM I 42,5 R & $300 \mathrm{~kg} / \mathrm{m}^{3}$ \\
\hline 0-4 Bratčice & $800 \mathrm{~kg} / \mathrm{m}^{3}$ & 0-4 Bratčice & $700 \mathrm{~kg} / \mathrm{m}^{3}$ \\
\hline 4-8 Tovačov & $250 \mathrm{~kg} / \mathrm{m}^{3}$ & 4-8 Tovačov & $228 \mathrm{~kg} / \mathrm{m}^{3}$ \\
\hline $\begin{array}{l}4-31.5 \text { pene- } \\
\text { trated concrete } \\
\text { recyclate }\end{array}$ & $620 \mathrm{~kg} / \mathrm{m}^{3}$ & $\begin{array}{l}\text { 0-16 raw } \\
\text { concrete } \\
\text { recyclate }\end{array}$ & $690 \mathrm{~kg} / \mathrm{m}^{3}$ \\
\hline water & $147 \mathrm{~kg} / \mathrm{m}^{3}$ & water & $159 \mathrm{~kg} / \mathrm{m}^{3}$ \\
\hline- & - & $\begin{array}{l}\text { blast-furnace } \\
\text { slag }\end{array}$ & $90 \mathrm{~kg} / \mathrm{m}^{3}$ \\
\hline
\end{tabular}

Table 5. Formulations of concrete mixtures III

\section{Formulation $\mathbf{R 5}$}

$100 \%$ of natural coarse aggregate $8-16 \mathrm{~mm}$ substituted with raw concrete recyclate $0-16 \mathrm{~mm}$

\begin{tabular}{cc|cc}
\multicolumn{2}{c|}{$0-16 \mathrm{~mm}$} & \multicolumn{2}{c}{ recyclate $0-16 \mathrm{~mm}$} \\
\hline CEM I 42,5 R & $300 \mathrm{~kg} / \mathrm{m}^{3}$ & CEM I 42,5 R & $300 \mathrm{~kg} / \mathrm{m}^{3}$ \\
\hline $0-4$ Bratčice & $700 \mathrm{~kg} / \mathrm{m}^{3}$ & $0-4$ Bratčice & $760 \mathrm{~kg} / \mathrm{m}^{3}$ \\
\hline $\begin{array}{c}4-8 \text { Tovačov } \\
0-16 \text { raw }\end{array}$ & $228 \mathrm{~kg} / \mathrm{m}^{3}$ & $4-8$ Tovačov & $228 \mathrm{~kg} / \mathrm{m}^{3}$ \\
\hline $\begin{array}{c}\text { concrete recy- } \\
\text { clate }\end{array}$ & $690 \mathrm{~kg} / \mathrm{m}^{3}$ & $\begin{array}{c}0-16 \text { raw } \\
\text { concrete recy- } \\
\text { clate }\end{array}$ & $690 \mathrm{~kg} / \mathrm{m}^{3}$ \\
\hline water & $159 \mathrm{~kg} / \mathrm{m}^{3}$ & water & $159 \mathrm{~kg} / \mathrm{m}^{3}$ \\
\hline fly ash & $90 \mathrm{~kg} / \mathrm{m}^{3}$ & microsilica & $30 \mathrm{~kg} / \mathrm{m}^{3}$ \\
\hline
\end{tabular}

\section{Formulation R6} $100 \%$ of natural coarse aggregate 8-16 mm substituted with raw concrete recyclate $0-16 \mathrm{~mm}$ 
slabs (always without and with $12 \%$ of dispersion - see Table 6). In the case of raw concrete recyclate (see Table 3, Form. R2; Table 4, Form. R4; Table 5, Form. R5 and R6), the increase of fine particles content of the recyclate was compensated for by the lower amount of natural aggregate $0-4$ Bratčice and 4-8 Tovačov. Also in the case of adding slag and fly ash, the proportion of fine natural aggregate was reduced, the amount of cement remaining constant (see Table 4, Form. R4; Table 5, Form. R5).

\section{Methods}

\subsection{Production and storage of specimens}

To make 12 test slabs, the total of 6 double mixtures were made in the forced mixer. It means that 1 pair of slabs was made from one mixture, namely with and without the addition of $12 \%$ dispersion. The first mixture in each pair was always thicker (Table 6) with a consistency of S1; the remaining mixture was, after adding a liquid dispersion $(0.262 \mathrm{~kg}$ of dispersion E $160 \mathrm{~V} 55+0.027 \mathrm{~kg}$ of the Telalit 1040 hardener), mixed again and used, with a consistency of S3, for making the second one from the pairs of slabs. After 48 hours of setting and hardening, the specimens were demoulded and stored in an environment with a relative humidity of $95 \%$ (ČSN EN 12390-2 Making and curing specimens for strength tests) for 56 days. This type of storage was chosen in order to eliminate the possible leaching of epoxy dispersion in one half of the specimens. Then all the 12 concrete slabs designated for the durability tests and supplementary mechanical tests were dried in an electric dryer at a temperature of $105^{\circ} \mathrm{C}$ for 48 hours. Before carrying out the actual tests of permeability of the surface layer of concrete of all the slabs, their residual moisture content was determined by means of the KAKASO capacity hygrometer using the calibration curves (Fig. 5).

\subsection{Durability - permeability tests}

The tests of permeability of the cover layer of concrete were carried out on the dried and cooled specimens with an average age of 65 days. The influence of concrete moisture content on the results of the Torrent permeability measurement has already been studied by Romer (2005). In order to achieve a perfect contact of the devices with the concrete surface, the tests were carried out on the smooth reverse side of the concrete slabs. On the reverse side of each slab, three TORRENT air permeability tests (Fig. 1), two GWT pressure water permeability tests (Fig. 2), and two ISAT tests of initial surface absorption (Fig. 3) were carried out.

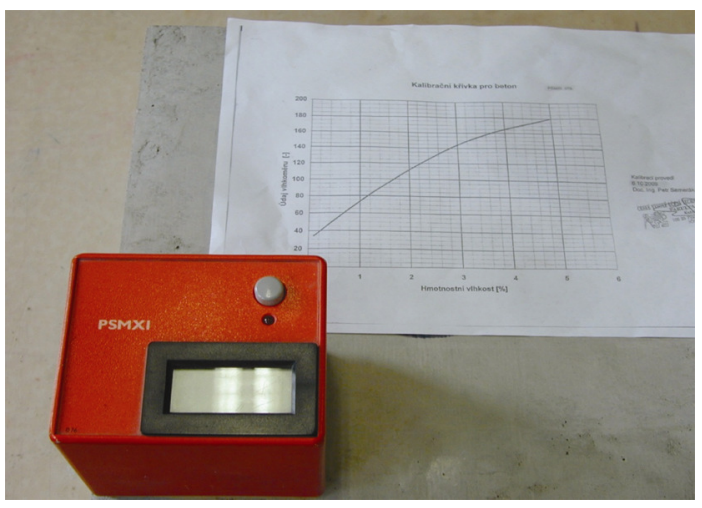

Fig. 5. KAKASO capacity hygrometer including calibration curve

\subsection{Supplementary tests of mechanical properties}

Since durability tests do not noticeably damage the integrity of the tested slabs, it is advantageous to divide each slab into a set of smaller specimens which would be suitable for mechanical tests. After 90 days of curing, each slab of $300 \times 300 \times 80 \mathrm{~mm}$ was cut into 3 cubes with the dimensions of $80 \times 80 \times 80 \mathrm{~mm}$ for the compressive strength test, and one prism with the dimensions of $300 \times 60 \times 80 \mathrm{~mm}$ for the flexural strength test. The tests were carried out and evaluated in accordance with ČSN EN 12390-3 Testing hardened concrete - Part 3: Compressive strength of test specimens and ČSN EN 12390-5 Testing hardened concrete - Part 5: Flexural strength of test specimens.

Table 6. Composition, marking and workability of concretes of the 12 test slabs $300 \times 300 \times 80 \mathrm{~mm}$

\begin{tabular}{|c|c|c|c|c|c|c|c|c|}
\hline 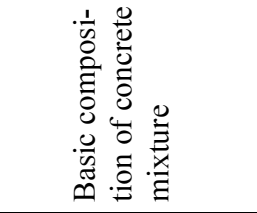 & 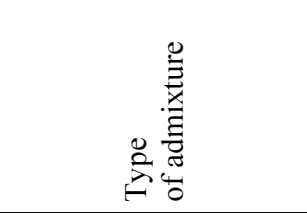 & 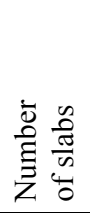 & 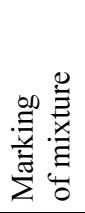 & $\begin{array}{l}\tilde{y} \\
\frac{\tilde{J}}{0} \\
\frac{0}{\Xi} \\
\frac{\Xi}{n}\end{array}$ & 晜莺 & 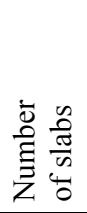 & 品 & 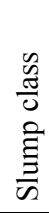 \\
\hline reference & none & 1 & R1 & S1 & \multirow{6}{*}{$\begin{array}{c}12 \% \text { of epoxy dispersion } \\
\text { E160V55 }\end{array}$} & 1 & R1E & $\mathrm{S} 3$ \\
\hline raw recyclate & none & 1 & $\mathbf{R 2}$ & S1 & & 1 & R2E & S3 \\
\hline penetrated recyclate & none & 1 & $\mathbf{R 3}$ & S1 & & 1 & R3E & $\mathrm{S} 3$ \\
\hline \multirow[t]{3}{*}{ raw recyclate } & $30 \%$ blast-furnace slag & 1 & R4 & S1 & & 1 & R4E & S3 \\
\hline & $30 \%$ fly ash & 1 & R5 & $\mathrm{S} 1$ & & 1 & R5E & S3 \\
\hline & $10 \%$ microsilica & 1 & R6 & S1 & & 1 & R6E & S3 \\
\hline
\end{tabular}




\section{Results and discussion}

\subsection{Moisture content of test slabs before permeability tests}

Water contained in the capillaries of concrete influences markedly its permeability for water, air and other gases. Before the actual testing, it is therefore necessary to decrease the moisture content of concrete specimens to the minimum. The bar chart in Figure 6 compares the decreases in moisture content of the concrete slabs after 48 hours of drying at $105{ }^{\circ} \mathrm{C}$ and informs us about the actual residual moisture content of slabs made according to individual formulations. The decrease in moisture content of slab concretes is always related to the initial moisture content before placing the slabs into the dryer.

The greatest decrease in moisture content occurs in concretes with aggregate, which absorbs little moisture, i.e. natural dense aggregate (Form. R1), and with a recyclate penetrated with dispersion (Form. R3). Both these types of aggregate contain a minimum of water and besides, the saturated larger pores of cement mortar dry up faster in comparison with the aggregate. On the other hand, concretes with porous concrete recyclate and a greater amount of the batch of water (Form. R2) dry out more slowly because water is absorbed also in the recyclate. Concretes with porous concrete recyclate and with an addition of very fine fillers (Form. R4-R6) hold the physically bound water for even a longer time due to their finer pore structure. The effect of wettability of the surface of fine aggregate is also apparent in the values of residual moisture content of concretes immediately before the permeability tests. The highest residual moisture content was found in the concrete with the addition of fly ash, microsilica and, potentially, dispersion (Form. R5, R6, or pot. R6E).

\subsection{Durability - TORRENT air permeability test}

The alignment charts in Figure 7 show air permeability values of the surface layer of concretes made according to six formulations determined using the TORRENT method. Both charts show the decrease in permeability of concretes in which natural coarse aggregate was replaced with concrete recyclate. A further decrease in permeability is caused by an addition of fine silicate admixtures. The lowest permeability values were obtained in samples with the highest residual moisture content (R4, R5 and R6). It has been reported (Terzijski 1984; Jacobs, Hunkeler 2006) that wet concrete can give misleading (too low) results in the permeability test. On the other hand, the highest values of permeability were obtained in the samples with dense aggregate both with and without dispersion added into the batch of water (R1, R1E), both specimens having a very low residual moisture content $(0.02 \%$ - see Fig. 6). High values of permeability in concretes with dense aggregate can also be explained from a purely mechanical point of view on the basis of mainly circled natural grains in comparison with the "bulk mass" barrier of porous concrete recyclate. This "geometrical factor" seems effective for reducing permeability.
Loss of moisture of concrete slabs $300 \times 300 \times 80 \mathrm{~mm}$ by drying (48 hours at $105^{\circ} \mathrm{C}$ ), remaining moisture before permeability test indicated above the columns in \%

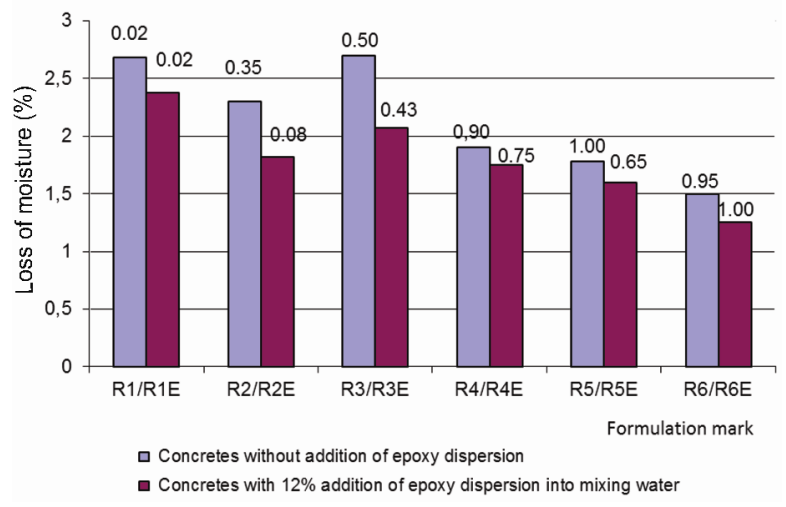

Fig. 6. Moisture content decrease and residual moisture content of concrete slabs after 48-hour drying

It is interesting that the $12 \%$ addition of dispersing additive into the batch of water increases substantially the air permeability of concretes without fine silicate admixtures (Antonovič et al. 2010; Wong et al. 2011) - it is apparent from Figure 6 that the specimens of concrete with dispersion (purple columns) dry out faster and their resulting residual moisture content is lower. In concretes with admixtures it becomes apparent, in the phase of mixing and subsequently hardening, that they have a considerable specific surface which is able to physically bind the surplus water in the mixture in the long run. In the case of concretes without dispersion containing more porous aggregate - water can be absorbed into aggregate and thus affect the results.

\subsection{Durability - GWT and ISAT permeability tests for water}

The alignment charts in Figure 8 show the values of water flow through the concrete layer of six tested slabs made from formulations R1, R1E to R6, R6E determined using the GWT method and the Eqn (1). It is possible to say that the higher flow of water through the concrete layer can be predicted from the higher porosity of the dry concrete recyclate (Form. R2) and further increased by alternately adding fine-grained silicate admixtures (Form. R4, R5), especially microsilica (Form. R6). Similarly the charts in Figure 9 show the values of water flow through the layer of tested concretes determined by means of the ISAT method and the Eqn (2). The result is comparable with the previous permeability test carried out using the GWT method. It is again possible to say that the higher flow of water is given by a higher porosity of the raw recyclate and by an addition of fine-grained silicates with high specific surface area.

Water, bound in the pores of the recyclate in a capillary way and physically bound to the surface of fine admixtures, probably creates a sort of conducting highway for the subsequent flow of additional liquid. However, the influence of fine admixtures on increasing the permeability of concretes for water remains disputable with a view to their puzzolana reaction contributing 
Permeability coefficient of surface layer of concrete slab $300 \times 300 \times 80 \mathrm{~mm}-$ TORRENT test

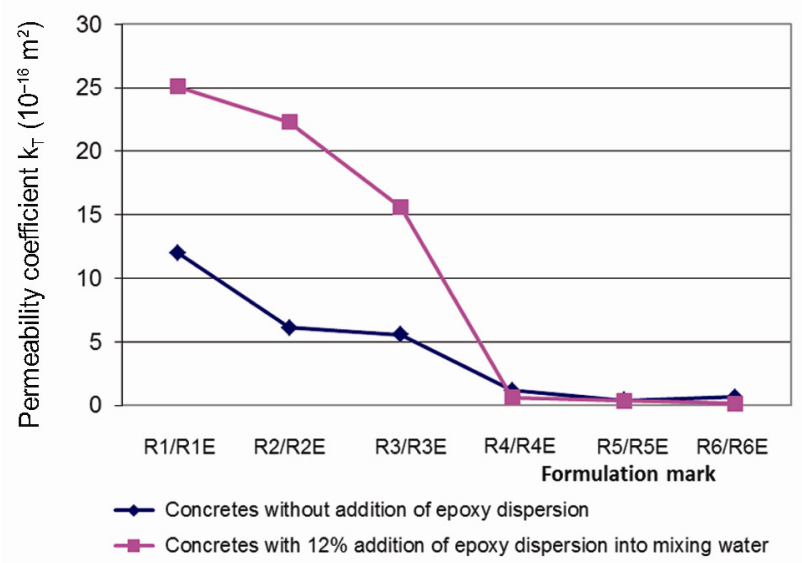

Fig. 7. Change in the air permeability coefficient $\mathrm{k}_{\mathrm{T}}$ in the tested types of concrete

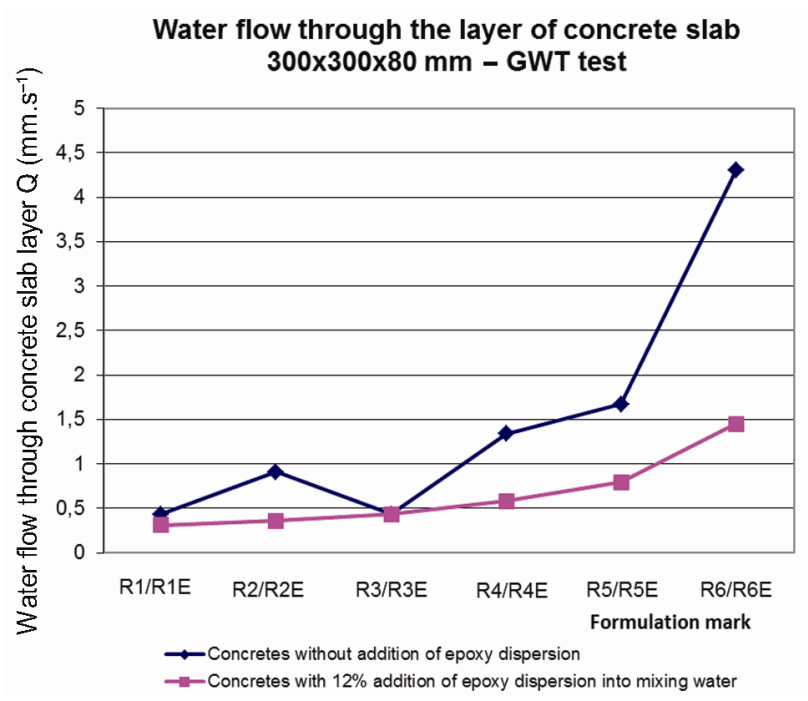

Fig. 8. Change in the water flow through the concrete layer Q in the tested types of concrete

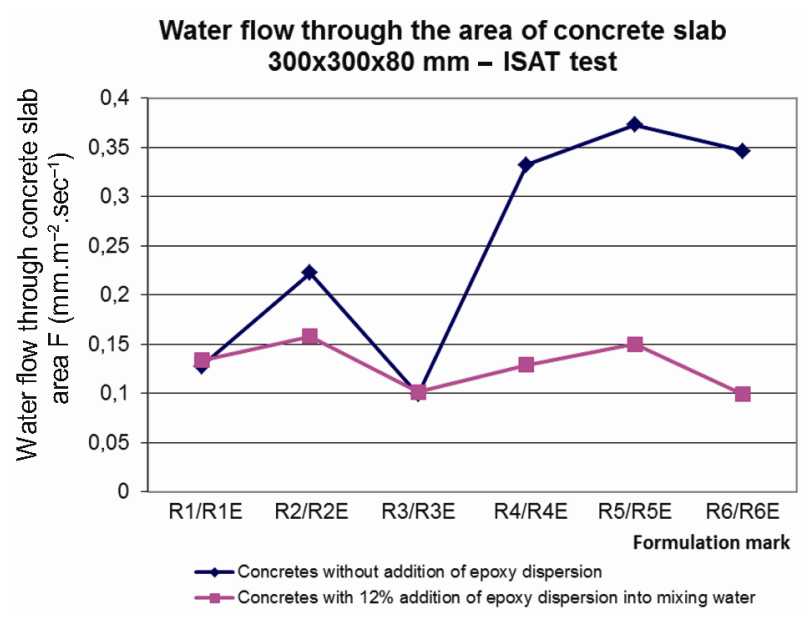

Fig. 9. Change in the water flow through the concrete area $\mathrm{F}$ in the tested types of concrete rather to decreasing the capillarity of concrete. If we compare the results of air permeability from the TORRENT test with those of water permeability, it is possible to point out (Figs 8 and 9) the apparent positive influence of the $12 \%$ addition of solvent-free epoxy dispersion on the abrupt decrease of the permeability of concretes made of recycled concrete. The addition of $12 \%$ dispersion into the batch of water probably seals both the porous aggregate and capillaries in silicate admixtures and the concrete permeability for water is limited to the cement paste only.

\subsection{Supplementary tests of mechanical properties}

The mechanical properties of concretes made of recycled concrete after adding, alternately, additives and admixtures were studied in detail by Stehlík (2010a, b, 2011b) in the previous years. However, because of the anticipated connection between durability and the mechanical properties, the tested types of concretes made according to formulations R1, R1E to R6, R6E were tested again for the compressive strength and tensile strength in bending. Two pairs of alignment charts in Figure 10 illustrate the change in the 90-day compressive strengths (upper pair - without and with dispersion) and tensile strengths in bending (lower pair - without and with dispersion) in concrete specimens made according to the twelve formulations. It is possible to say that concretes made of concrete recyclate achieve worse results compared to the reference concretes, i.e. concretes with dense natural aggregate. In two of the formulations it is possible to track a certain positive divergence in the compressive strength. In the case of concrete made of concrete recyclate with a combined addition of $30 \%$ of blast-furnace slag and $12 \%$ of epoxy dispersion (Form. R4E) the compressive strength achieves $30 \mathrm{MPa}$, in concrete with a combined addition of $10 \%$ of microsilica and $12 \%$ of epoxy dispersion then $25 \mathrm{MPa}$ (Form. R6E), which are values higher than or at least comparable with the reference concrete. On the other hand, the influence of epoxy dispersion on the change in the tensile strength in bending of the tested concretes from the twelve formulations can surprisingly be neglected.

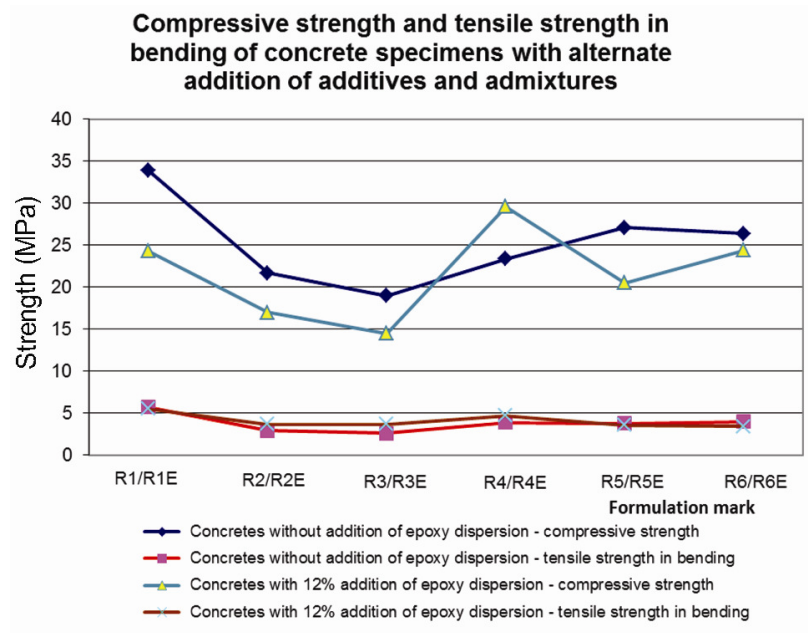

Fig. 10. Change in the compressive and tensile strength in bending in the tested types of concrete 


\subsection{Durability - permeability tests and supplementary tests of mechanical properties - overall evaluation}

On the basis of the data found out in this research (the evaluation of durability of concretes made of concrete recyclate treated by alternately adding additives and admixtures) it is possible to conclude:

- The content of porous aggregate alone (Form. R2, $\mathrm{R} 2 \mathrm{E}$ ) or including very fine admixtures (Form. R4, R4E-R6, R6E) contributes to retaining physically bound water in concrete and in fact markedly extends the time of its drying. Almost identical conclusions can be found in the chemical-physical publications (Šauman 1965; Henning, Lach 1983);

- The air permeability of surface layer of cured concrete made of concrete recyclate is substantially influenced not only by the density of cement paste, but also by the type, bulk-mass, porosity and geometrical factor of the aggregate. The impact of adding additives and fineness or the specific surface of admixtures is also not negligible. Also according to Gómez-Soberón (2002) the porosity (determined with mercury intrusion porosimetry) of concrete increases considerably when natural dense aggregate is replaced by concrete recyclate;

- The air permeability of surface layer of concrete made of concrete recyclate is markedly increased by adding a dispersion additive into the mixing water; it is, however, decreased by silicate admixtures with a high specific surface;

- The decrease in air permeability of the surface layer of concrete made of concrete recyclate compared to concrete made of dense aggregate is caused by a higher residual moisture content after 48 hours of drying. Wet concrete can give misleading results in the permeability test;

- The pressure water permeability of the surface layer of concrete made of concrete recyclate is, similarly as air permeability, substantially influenced by the density of cement paste, type, bulk-mass, porosity and specific surface of the aggregate and by specific surface of admixtures, and naturally also by the type of additive. The values of permeability of the surface layer or area of concrete for water are, however, incomparable with those of air permeability. Both these phases have a diametrically different size of molecules, they are compressible in a different way and they are bound by different forces in the pores of concrete;

-A stronger flow of water through the layer or area of concrete made of concrete recyclate is a consequence of the higher porosity of the recyclate (similarly observed by Gómez-Soberón (2002) and Sun, Jiang (2010)) and can even be increased by an alternate addition of fine silicate admixtures;

- The flow of water through the layer or area of concrete made of concrete recyclate can be markedly decreased by adding a dispersion into the mixing water, which causes the closing of pores and capil- laries in the aggregate as well as in admixtures in the concrete. However, the dependence of the total permeability of concrete on the absorption capacity and diffusivity of porous aggregate and fine admixtures was not explained unambiguously even by Zaharieva et al. (2003);

- The compressive strengths of concretes made of concrete recyclate can be improved by adding silicate admixtures and dispersion additives; the combination of $30 \%$ of slag or $10 \%$ of microsilica with $12 \%$ of epoxy dispersion seems to be promising.

\section{Conclusion}

The presented research has confirmed that it is possible to modify the cover layer permeability (which is one of the most important durability characteristics of concretes) and partially also strength of concretes made of concrete recyclate by adding a variant combination of silicate admixtures and dispersion additives. What must be taken into account is the state of the future aggressive medium. In the case of placing concretes made of concrete recyclate into an environment with aggressive gases it is convenient to add approx. 10-30\% of fine silicate admixtures into the fresh mixture, the addition of dispersion additives does not bring any major benefit. However, it is necessary to be careful about the misleading results of air permeability of concretes with different residual moisture content. In the case of placing concretes into an environment with aggressive liquids it is convenient to add approx. $12 \%$ of polymer epoxy dispersion into the mixing water. The dispersion partially seals both pores in the concrete recyclate and capillaries in the silicate admixtures. The addition of fine silicate admixtures is, on the contrary, not suitable. Similarly, but to a lesser extent, it is possible to improve the strength of concrete from concrete recyclate by a variant addition of slag or microsilica with epoxy dispersion. However, the price of most additives and admixtures (the price for the most expensive component, epoxy dispersion, is about $140 €$ at a dose of $12 \%$ of the cement mass per $1 \mathrm{~m}^{3}$ of fresh concrete) is too high for their massive application. It is therefore possible to expect a targeted modification of durability, and to a limited extent also strength, in only a narrow spectrum of concretes made of recycled concrete, e.g. waterworks concretes, sulphate-resisting concretes, carbonationresisting concretes, etc.

\section{Acknowledgements}

This work was supported by the Research Project of the Ministry of Education and Youth of the Czech Republic No. VVZ MSM 0021630511 "Progressive Building Materials with Utilization of Secondary Raw Materials and Their Impact on Structures Durability" and by the GA ČR 13-18870S "Assessment and Prediction of the Concrete Cover Layers Durability”. 


\section{References}

Antonovič, V.; Pundienė, I.; Stonys, R.; Čèsnienė, J.; Kerienè, J. 2010. A rewiew of the possible applications of nanotechnology in refractory concrete, Journal of Civil Engineering and Management 16(4): 595-602. http://dx.doi.org/10.3846/jcem.2010.66

Bai, J.; Gailius, A. 2009. Consistency of fly ash and metakaolin concrete, Journal of Civil Engineering and Management 15(2): 131-135. http://dx.doi.org/10.3846/13923730.2009.15.131-135

Bilir, T. 2011. Effects of non-ground slag and bottom ash as fine aggregate on concrete permeability properties, Construction and Building Materials 26(1): 730-734. http://dx.doi.org/10.1016/j.conbuildmat.2011.06.080

Claisse, P. A.; Elsayad, H. I.; Ganjian, E. 2009. Water vapour and liquid permeability measurements in cementitious samples, Advances in Cement Research 21(2): 83-89. http://dx.doi.org/10.1680/adcr.8.00046

Claisse, P. A.; Elsayd, H. I.; Shaaban, I. G. 1997. Absorption and sorptivity of cover concrete, Journal of Materials in Civil Engineering 9(3): 105-110. http://dx.doi.org/10.1061/(ASCE)08991561(1997)9:3(105)

Corinaldesi, V.; Moriconi, G. 2009. Influence of mineral additions on the performance of $100 \%$ recycled aggregate concrete, Construction and Building Materials 23(8): 2869-2876.

http://dx.doi.org/10.1016/j.conbuildmat.2009.02.004

Cui, H. Z.; Xiang, F. 2011. Study of surface modification of recycled aggregate and interfacial zone microstructure of the concrete, Advanced Materials Research 150-151: 313-316.

Debieb, F.; Courard, L.; Kenai, S.; Degeimbre, R. 2010. Mechanical and durability properties of concrete using contaminated recycled aggregates, Cement and Concrete Composites 32(6): 421-426.

http://dx.doi.org/10.1016/j.cemconcomp.2010.03.004

Gómez-Soberón, J. M. V. 2002. Porosity of recycled concrete with substitution of recycled concrete aggregate, Cement and Concrete Research 32(8): 1301-1311. http://dx.doi.org/10.1016/S0008-8846(02)00795-0

Henning, O.; Lach, V. 1983. Chemie ve stavebnictví [Chemistry in building industry]. Praha: SNTL, 63-69.

Henry, M.; Pardo, G.; Nishimura, T.; Kato, Y. 2011. Balancing durability and environmental impact in concrete combining low-grade recycled aggregates and mineral admixtures, Resources, Conservation and Recycling 55(11): 1060-1069.

http://dx.doi.org/10.1016/j.resconrec.2011.05.020

Hwang, E. H.; Ko, Y. S.; Jeon, J. K. 2007. Effect of polymer cement modifiers on mechanical and physical properties of polymer-modified mortar using recycled waste concrete fine aggregate, Journal of Industrial and Engineering Chemistry 13(3): 387-394.

Izaguirre, A.; Lanas, J.; Álvarez, Z. I. 2010. Ageing of lime mortars with admixtures: durability and strength assessment, Cement and Concrete Research 40(7): 1081-1095. http://dx.doi.org/10.1016/j.cemconres.2010.02.013

Jacobs, F.; Hunkeler, F. 2006. Non destructive testing of the concrete cover - evaluation of permeability test data, in Proc. of The International RILEM Workshop on "Performance based evaluation and indicators for durability", 19-21 March, 2006, Madrid, Spain.
Klimešová, Š.; Puchýř, M.; Schlattauer, P. 2001. Kamenivo $\mathrm{z}$ betonového recyklátu a prísady stavební chemie [Concrete recyclate aggregate and addition of building chemicals], Stavitel 3(1): 28-29.

Kwan, W. H.; Ramli, M.; Kam, K. J.; Sulieman, M. Z. 2012. Influence of the amount of recycled coarse aggregate in concrete design and durability properties, Construction and Building Materials 26(1): 565-573.

Matoušek, M.; Drochytka, R. 1998. Atmosférická koroze betonu [Atmospheric corrosion of concrete]. Praha: IKAS+ČKAIT, $10-75$.

Mlčochová, V. 2006. Nové poznatky z oblasti recyklovaných betonů [New findings about recycled concrete], in Proc. of the Recycling 2006, Brno, 2006. Brno: BUT and Association for the development of building materials recycling in the Czech Republic, 72-78.

Novák, J. 2009. Vodou ředitelné epoxidové disperse nové generace [Waterborne epoxy dispersions of new generation]. Annual state of project report FT-TA3/056. Pardubice, Czech Republic: SYNPO Pardubice.

Novák, J.; Hyršl, J.; Janovský, M.; Koukal, J.; Stehlík, M. 2006. Př́íprava epoxidových disperzí [Preparation of epoxy dispersions], in New Generation of Waterborne Epoxy Dispersions. Selected papers, Report of the SYNPO a.s. research institute, Ed. F. Socha. Czech Republic, Pardubice: SYNPO a.s., 8-18.

Novák, J.; Hyršl, J.; Janovský, M.; Koukal, J.; Stehlík, M. 2008. Využití epoxidových disperzí ve stavebnictví [Use of epoxy dispersions in the building industry], in New Generation of Waterborne Epoxy Dispersions. Selected papers, Report of the SYNPO a.s. research institute, Ed. F. Socha. Czech Republic, Pardubice: SYNPO a.s., 25-33.

Ohama, Y. 1995. Properties of latex-modified systems, Handbook of polymer-modified concrete and mortars. New York: Noyes publications, 132-157.

Pavlík, V.; Bajza, A.; Rousseková, I.; Unčík, S.; Dubík, M. 2007. Degradation of concrete by flue gases from cole combustion, Cement and Concrete Research 37(7): 10851095. http://dx.doi.org/10.1016/j.cemconres.2007.04.008

Pytlík, P. 2000. Technologie betonu [Concrete technology]. Brno: VUTIUM Brno, 304-310 and 366-371.

Pytlík, P. 2009. Recyklace betonu [Concrete recycling], in Proc. of the Special Concretes, February, 2009, Beroun, Czech Rep.

Rao, A.; Jha, K.; Misra, S. 2007. Use of aggregates from recycled construction and demolition waste in concrete, Resources Conservation and Recycling 50(1): 71-81. http://dx.doi.org/10.1016/j.resconrec.2006.05.010

Richardson, F. B. 1988. Waterborn epoxy coatings: past, present and future, Modern Paint and Coatings 4(1): 78-84.

Romer, M. 2005. Effect of moisture and concrete composition on the Torrent permeability measurement, Materials and Structures 38(279): 541v547.

Šauman, Z. 1965. Úvod do obecné fyzikální chemie a základy fyzikálni chemie silikátů [Introduction to general physical chemistry and fundamentals of physical chemistry of silicates]. $1^{\text {st }}$ ed., p. 140-159, SNTL, Praha 1965.

Schulze, W.; Tischer, W.; Ettel, W.; Lach, V. 1990. Necementové malty a betony [Non-cement mortars and concretes]. Praha: SNTL, 237-255.

Sebök, T. 1985. Př́sady a př́davky do malt a betonů [Additives and admixtures to mortars and concretes]. Praha: SNTL, 133-139. 
Škopán, M. 2006. Analýza stavu recyklace stavebních a demoličních odpadů a strategie dalšího rozvoje [Analysis of the situation in the recycling of building and demolition waste and the strategy of future development], in Proc. of the Recycling 2006, Brno, 2006. Brno: BUT and Association for the development of building materials recycling in the Czech Republic, 32-44.

Šmerda, Z.; Adámek, J.; Keršner, Z.; Meloun, V.; Mencl, V.; Novák, D.; Rovnaníková, P.; Teplý, B. 1999. Životnost betonových staveb [Life of concrete structures]. Praha: ČKAIT, 89-170.

Stehlík, M. 2011a. Combination of epoxy dispersion and ceramic admixtures for improving the quality of concretes from concrete recyclate, in Proc. of the International Symposium Recycling 2011, Brno, Czech Republic, 17-18 March, 2011. Selected papers, Ed. M. Škopán. Brno: VUT Brno, 93-100.

Stehlík, M. 2011b. Testing the strength of concrete made from raw and dispersion-treated concrete recyclate by addition of additives and admixtures, Journal of Civil Engineering and Management 19(1): 107-112. http://dx.doi.org/10.3846/13923730.2012.734853

Stehlík, M.; Anton, O.; Heřmánková, V.; Vítek, L. 2010a. Modification of concrete recyclate with variant combinations of additives and admixtures, in Proc. of the Testing and Quality in the Building Industry 2010, Brno, 5-6 October, 2010. Brno: BUT, 127-135.

Stehlík, M.; Anton, O.; Heřmánková, V.; Vítek, L. 2010 b. Treatment of concrete made of concrete recyclate with a water born epoxy dispersion of new generation, in Proc. of Sanace 2010, Brno, 21-22 April, 2010. Brno: Concrete Construction Repair Association, 441-449.
Sun, J.; Jiang, H. 2010. Study on properties of recycled concrete aggregate and influence of it on properties of concrete, in RILEM Proc. of the $2^{\text {nd }}$ International Conference of Waste Engineering Management, ICWEM 2010, 13-15 October, 2010. Selected papers. Shanghai, Tongji University, China, 73: 261-268.

Terzijski, I. 1984. Základy měrení propustnosti kompozitních silikátových materiálù [The fundamentals of permeability measurement of ceramics]. Report of the Geological Engineering Research Institute, Czech Republic, Brno, 5560.

Vavřín, F.; Retzl, K. 1987. Ochrana stavebního díla proti koro$z i$ [Protection of building structures from corrosion]. Praha: SNTL, 11-130.

Wong, H. S.; Pappas, A. M.; Zimmerman, R. W.; Buenfeld, N. R. 2011. Effect of entrained air voids on the microstructure and mass transport properties of concrete, Cement and Concrete Research 41(10): 1067-1077. http://dx.doi.org/10.1016/j.cemconres.2011.06.013

Zaharieva, R.; Buyle-Bodin, F.; Skoczylas, F.; Wirguin, E. 2003. Assesment of the surface permeation properties of recycled aggregate concrete, Cement and Concrete Composites 25(1): 223-232. http://dx.doi.org/10.1016/S0958-9465(02)00010-0

Michal STEHLÍK, doc., PhD, is educated in the field of physical and building material engineering. Nowadays, he works as an Associate Professor at the Department of Building Testing, Faculty of Civil Engineering, Brno University of Technology, Brno, Czech Republic. He is interested in polymer dispersions, treatment of recyclates, durability of concrete, carbonation of concrete, brick masonry. 